\title{
ISOBASES OF THE AIGONQUIN AND IROQUOIS BEACHES, AND THEIR SIGNIFICANCE ${ }^{1}$
}

BX JAMES WALTER GOIDTHWAIT

(Read before the Society December 28,1909 )

\section{CONTENTS}

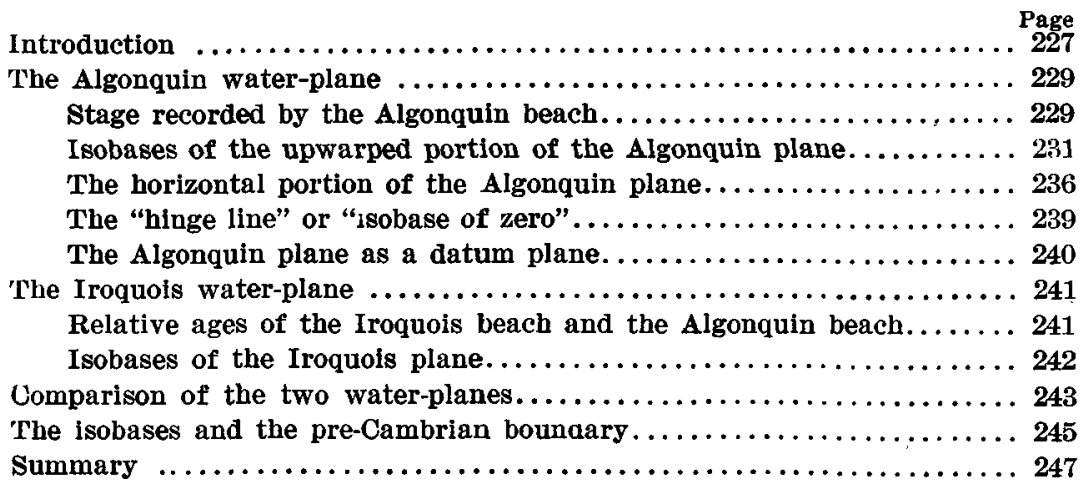

\section{INTRODUCTION}

The study of epeirogenic movements by means of critical surveys of raised beaches is one for which North America is a peculiarly rich field. The investigations of Gilbert in Lake Bonneville, of Upham in Lake Agassiz, and of Gilbert, Spencer, Leverett, Taylor, Fairchild, Coleman, Woodworth, and others in the Great Lakes region have contributed greatly to the understanding of post-glacial upwarpings. Among the many papers which have been written on this subject, one is unique in that it seeks to correlate observations over all eastern North America. This is the paper read before the Boston Society of Natural History in 1892 by Baron Gerard De Geer. ${ }^{2}$

\footnotetext{
${ }^{1}$ Manuscript received by the Secretary of the Soclety January 12, 1910.

2 Gerard De Geer: On Pleistocene changes of level in eastern North America. Pro. ceedings of the Boston Soclety of Natural History, vol. 25, 1892, pp. 454-477.
} 
'This distinguished visitor, fresh from studies of the upwarped marine strands of Scandinavia, applied himself at once to the task of correlating the measurements of raised beaches which had been made in New England, the maritime provinces, the Great Lakes region and the Northwest; and this correlation he reinforced with hurried though accurate observations of his own in New England and southeastern Canada. In order to show the upwarped form of the old "geoid surface" which he reconstructed, De Geer used a device which Gilbert had used ten years before in connection with Lake Bonneville ${ }^{3}$-he drew curves of equal deformation of the ancient water-plane. 'These he named "isanabases," or "isobases."4 They were not limited to the Atlantic Coast district which De Geer had personally examined, but were extended far into the interior, on the basis of measurements already secured around the Great Lakes by Gilbert, Spencer, Upham, and Todd, and in Labrador and the Hudson Bay region by Bell and Low. In view of the scarcity of data which De Geer had at his command and of the difficulties in correlation which he met by "interpolating" his geoid surface beneath deformed lake beaches of unknown ages, it is no wonder that his isobases for the Great Lake region hit wide of the mark. It would hardly have been surprising if his conclusions had been thoroughly discredited by later detailed investigations. On the contrary, however, De Geer's most fundamental conclusions seem to have been confirmed. The analogy which he drew between the North American and the Scandinavian uplifts appears to hold good; in both cases the movements were differential uplifts of a glaciated area, and in both the isobases follow so closely the boundary of pre-Cambrian areas that a causal connection between preCambrian oldlands, glaciation, and differential uplift is strongly suggested.

Since De Geer's map was published, the use of isobases seems to have been limited almost wholly to private studies; very few isobasic maps have been published, and even these concern districts of comparatively small extent. This has probably been due in most cases to the fact that measurements have not been numerous or accurate enough to make the isobases convincing, or even passably satisfactory. The fault has been in the data rather than in the method. One can easily see that an isobasic map is as valuable to the investigator of epeirogenic movements as a contour map is to the physiographer. If the data which we possess are too

${ }^{3}$ G. K. Gilbert: Contributions to the hlstory of Lake Bonneville. Second Annual Report of the U. S. Geological Survey, 1882, pp. 195-197, plates xlll and xlli1.

- Gerard De Geer: Quaternary changes of level In Scandinavia. Bulletin of the Geological Soclety of Amerlca, vol. 3, 1892, p. 66; and op. cit., Proceedings of the Boston Soclety of Natural History, vol. 25, 1892, p. 457. 
incomplete to justify the drawing of isobases, our efforts ought to be redoubled to accumulate data so accurate and so abundant that a set of isobases shall provoke no more skepticism than so many well-executed contour lines. Then, and not until then, can we hope to do much in analyzing the great upwarpings of late glacial time.

Good isobasic maps are valuable in two ways: First, as aids to fixing the relative ages of extinct lakes in different parts of a region; and, second, as indicators of the extent, nature, and cause of epeirogenic movements. The present paper touches both sides of the subject. Isobases for the Iroquois beach and the Algonquin beach will be compared, with a view to answering the question whether these two critical stages of the extinct lakes, Iroquois and Algonquin, are synchronous or not. The question of the nature and cause of the differential uplifts will be treated very briefly, because that is soon to be taken up by Mr. F. B. Taylor in a monograph which is now in preparation.

The data here used are from several sources, as references in every case will show. Most of the measurements of altitude of the Algonquin beach have been made iluring the last five years by the geological surveys of Wisconsin and Michigan, the U. S. Geological Survey, and the Geological Survey of Canada. These measurements are especially reliable, because they were made with the wye-level, rather than the hand-level or the aneroid barometer.

\section{The Algonquin Water-plane}

\section{STAGE RECORDED BY THE ALGONQUIN BEACH}

The Algonquin beach marks a critical stage in the history of Lake Algonquin. For some time previous the discharge of the ice-dammed lake had been entirely through the Trent Valley into the waters of the Lake Ontario basin along the "Algonquin River" (see figure 1). Differential uplifts, however, had been lifting this region with respect to more southerly districts, and the rising waters of the lake had been advancing on the shores in the Michigan and Huron basins. When the head of the Trent Talley, at Kirkfield, Ontario, had been lifted to an altitude as high as the pass at the south end of Lake Huron, that pass began to receive a share of the overflow which ran down the Saint Clair and Detwit rivers into Lake Erie. This two-outlet stage of the lake is

5 The names "Lake Algonquin," "Algonquin beach," and "Algonquin River" were first used by T. W. Spencer: Notes on the origin and history of the Great Lakes of North America. Proceedings of the American Association for the Advancement of Science, vol. 37,1889 , p. 199. 


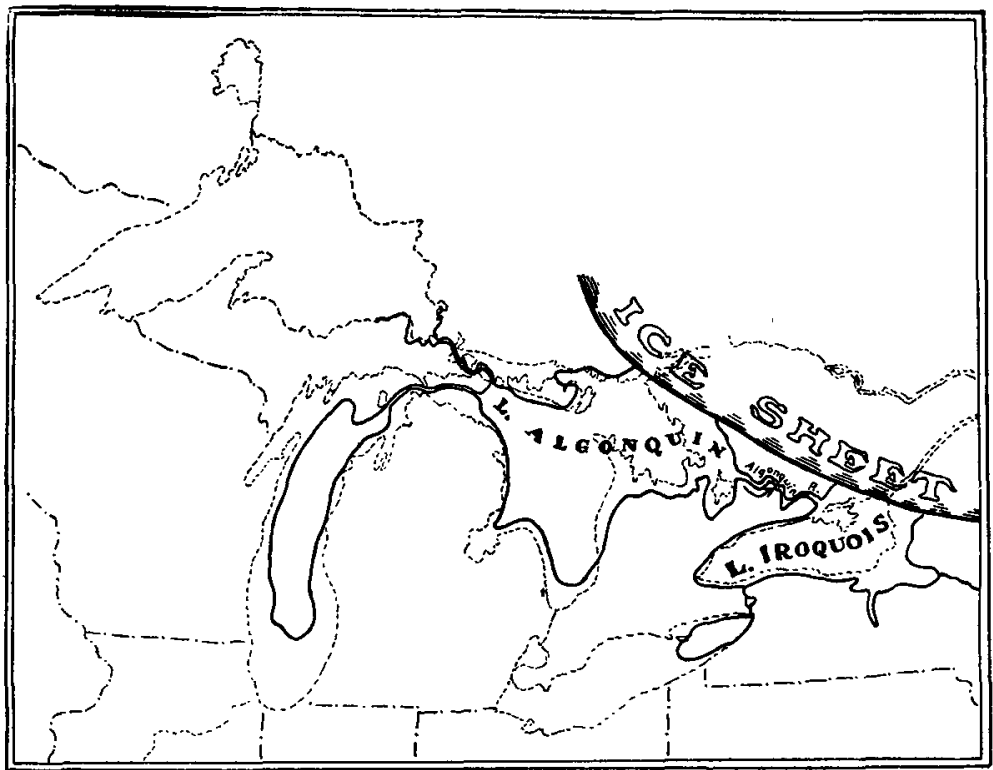

FIGURE 1.-Map of Lakes Algonquin and Iroquois

A short time previous to the date of construction of the Algonquin beach. (After Gilbert)

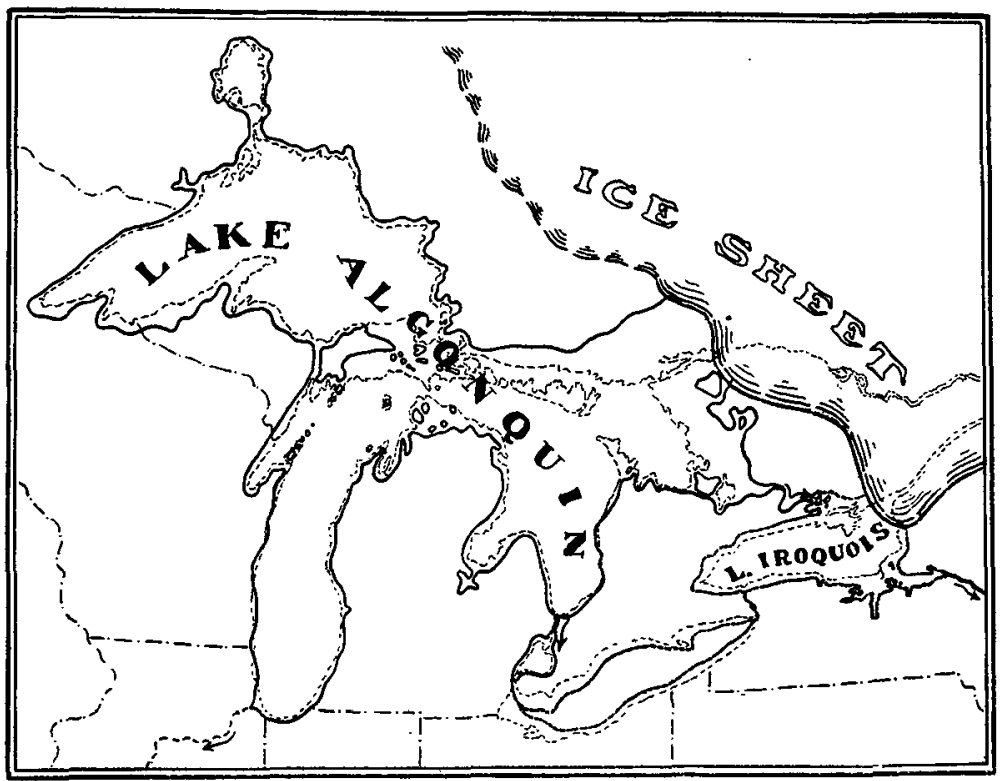

Figure 2.-Map of Lake Algonquin

At the stage marked by the Algonquin beach. The existence of Lake Iroquois at this time is doubtful. The position of the ice border is quite hypothetical 
the stage marked by the Algonquin beach (see figure 2 ). It lasted probably but a short time, for as the canting of the region proceeded the discharge was shifted entirely into the Saint Clair River, while the Trent Valley and surrounding shores of the lake emerged from the water. Thus a beach which had been under construction perhaps for centuries, during the regime of the Algonquin River and the slow rising of Lake Algonquin, was suddenly abandoned as the water-plane adjusted itself to the new outlet. The canting of the abandoned water-plane progressed until the beach at Kirkfield had been lifted 275 feet higher than it had stood during the two-outlet stage. ${ }^{6}$

Today the Algonquin beach can be followed somewhat continuously from the old outlet at the head of the Saint Clair River, where it stands 607 feet above sealevel, ${ }^{7}$ to the head of the more northerly outlet at Kirkfield, where its altitude is 883 feet. From here down the Trent Valley the course of the ancient Algonquin River is marked by a chain of extinct lakes and rapids which terminated in the contemporary waters of the I ake Ontario basin. ${ }^{\mathbf{8}}$

\section{ISOBASES OF THE UI'WARPED PORTION OF THE ALGONQUIN PLANE}

On the isobase map (plate 5) about 100 localities where the altitude of the Algonquin beach has been accurately determined are shown by round dots. In about 60 of these cases the measurements themselves are indicated in feet above sealevel. They are as follows:

Locallty feet
Authority

West side of Lake Michigan:

Burnt Bluff ....... 723

Deaths Door .......660 660

Rowleys Bay......654

Oconto .........6.620

Sturgeon Bay ......6.621

Cormier .........6611

Algoma ..........66 610

Two Rivers ........6 607

Eranston ........6.605

Rogers Park .......604
W. H. Hobbs, Michlgan Geological Survey. 1907.

J. W. Goldthwait, Wisconsin Geological and Natural History Survey, 1905.

Ditto.

Ditto.

Ditto.

Ditto.

Ditto.

Ditto.

J. W. Goldthwait, 1906.

Ditto.

- This sequence of events was first recognized by J. W. Spencer, loc. cit. It has been confirmed by observations of Gllbert and Taylor.

T Since Saint Clair River became the sole line of discharge of the lake, it has been deepened enough to lower the level of the waters in the Huron basin from $60 t$ feet to 581 feet above sealevel.

${ }^{8}$ Gilbert: The Algonquin River (Abstract). Amerlcan Geologist, vol. 18, 1896, p. 231. 


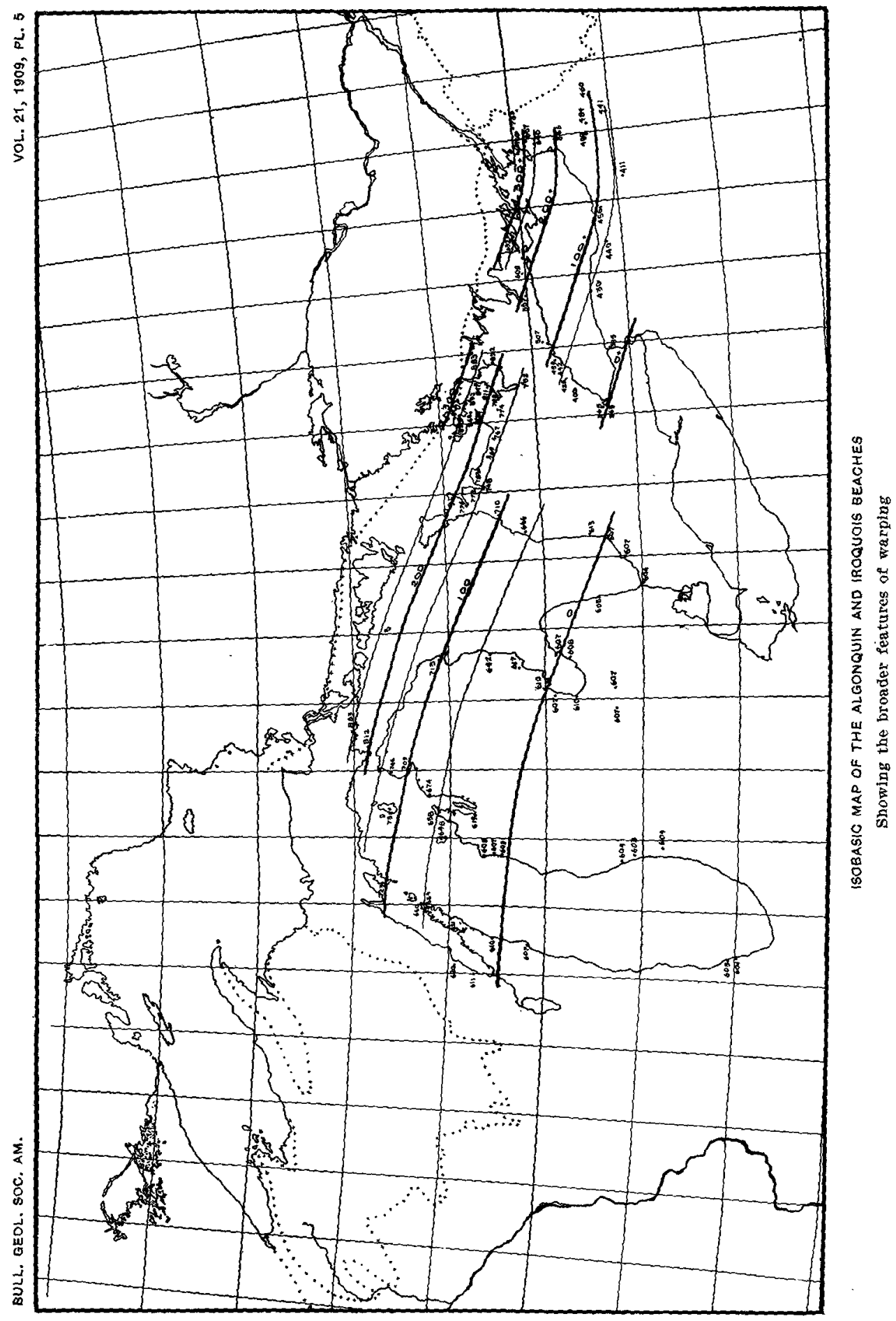


(reorgian Bay and Penetang Peninsula-Continued:

\begin{tabular}{|c|c|}
\hline Meaford $\ldots \ldots \ldots \ldots 783$ & $\begin{array}{l}\text { F. B. Taylor and J. W. Goldthwait, Cana- } \\
\text { dian Geological Survey, } 1908 \text {. }\end{array}$ \\
\hline Clarksburg ....... T69 & Ditto. \\
\hline Mair Mills ........ 767 & Ditto. \\
\hline Colwell ...........774 & Ditto. \\
\hline Penetang ........ 855 & Ditto. \\
\hline Wyebridge ........ 840 & Ditto. \\
\hline Ehmvale . . . . . . 829 & Ditto. \\
\hline Coldwater ........852 & Ditto. \\
\hline
\end{tabular}

Lake Simcoe district:

\begin{tabular}{|c|c|}
\hline Orillia $\ldots \ldots \ldots \ldots .847$ & Ditto. \\
\hline Oro $\ldots \ldots \ldots \ldots \ldots 811$ & itto. \\
\hline Barrie .......... 785 & \\
\hline Holland Landing .... 752 & Itto. \\
\hline Beaverton ....... & itto. \\
\hline Kirkfield ....... & \\
\hline
\end{tabular}

With hardly an exception these measurements were made with the wyelevel.

In regard to the data from localities east of Lake Huron and Georgian Bay, it should be said that the altitude of the Algonquin beach at most of these places was measured by Dr. J. W. Spencer in 188\%. With only two or three exceptions the new measurements of 1908 agree with those of Spencer, and bear witness to the accuracy of his work.

Isobases for every 50 feet of uplift between 0 and 300 have been drawn with reference to these localities. That the isobases accord properly with the 60 stations whose measurements have just been tabulated is easily seen on plate 5 . The accordance would be found to be just as good, however, if one selected at random any 60 of the 100 stations whose positions are shown by the dots. Detailed work on large-scale maps, the results of which have been published in other papers, ${ }^{\circ}$ testify to the remarkably complete harmony between isobases and measurements.

In preparing the following summary of the attitude of this warped water-plane, such details as directions and rates of tilt have been worked

\footnotetext{
- J. W. Goldthwait: Correlation of the raised beaches on the west side of Iake Michigan. Journal of Geology, vol. 14, 1906, pp. 411-424.

Abandoned shorelines of eastern Wisconsin. Bulletin of the Wisconsin Geological and Natural History Survey, no. 17, 1907.

A reconstruction of water-planes of the extinct glacial lakes in the Lake Michigan basin. Journal of Geology, vol. 16, 1908, pp. 459-476.

Preliminary report on measurements of altitude of the Algonquin and Nipissing shorelines in Ontario. July 6-August 11. 1908. Geological Survey of Canada. Summary Report of Director for 1908, pp. 112-114.

An instrumental survey of the shorelines of the extinct lakes Algonquin and Nipissing in southwestern Ontario. Geological Survey of Canada (In press).
} 
out from maps whose scales range from $1: 400,000$ to $1: 250,000$. Plate 5, prepared from a much smaller map, is intended merely to show the broader features of warping, not to serve as a basis for estimating minute details.

Over the northern, or, more accurately, the northeastern, part of the Michigan-Huron basins the Algonquin beach has been upwarped so that it now slants southward at a rate that decreases down the slope of the plane. The inclination ranges from about 5 feet per mile in the north to 3 feet, 2 feet, 1 foot and less toward the south, to where the beach actually becomes horizontal, over the southern half of IJake Michigan.

The directions and rates of tilt in different districts, worked out after all available wye-level measurements had been plotted on large-scale maps, are tabulated in detail on page 235 .

These figures have been tabulated again, in a more compact form, for the sake of comparison of tilt rates at corresponding altitudes in the different districts.

Tilt Rntes of the Algonquin. Beach arranged for Purposes of Comparison.

\begin{tabular}{|c|c|c|c|c|c|c|}
\hline \multirow{2}{*}{ District. } & \multicolumn{6}{|c|}{$\begin{array}{l}\text { Tilt rates, in feet per mile, between successive } \\
\text { isobases. }\end{array}$} \\
\hline & $0-50$ & $50-100$ & $100-150$ & $150-200$ & $200-250$ & $250-300$ \\
\hline $\begin{array}{l}\text { Lake Michigan and Straits } \\
\text { of Mackinac............. }\end{array}$ & 1.16 & 1.82 & 2.85 & 3.33 & 3.40 & \\
\hline West side of Lake Huron... & 0.75 & 2.22 & & & & \\
\hline 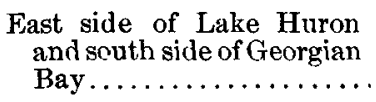 & 1.02 & 2.10 & 2.11 & & & \\
\hline Lake Simese district. & & & & 2.68 & 3.00 & 1300 \\
\hline Average tilt rates & 0.97 & 2.05 & 2.48 & $: 309$ & $3: 0$ & 6.00 \\
\hline
\end{tabular}

Not a small part of the discrepancies hetween tilt rates in the same vertical column in this table may be due to the necessity of taking stations which do not lie exactly on the isobases, and whose differences of altitude are consequently not 50 feet, but range from 32 feet to 71 feet. Detailed isobase maps drawn on a large scale show that the tilt rate is more uniform between jonhases than one might at first suppose from the 


\begin{tabular}{|c|c|c|c|c|c|c|c|c|c|c|c|c|c|}
\hline & & 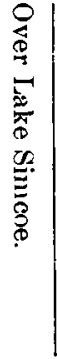 & & & 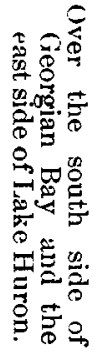 & & 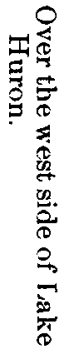 & & & & & 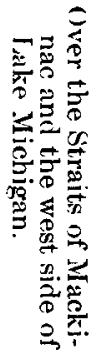 & $\underset{\bar{X}}{\stackrel{5}{3}}$ \\
\hline 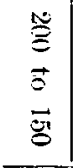 & 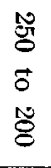 & $\begin{array}{l}\tilde{\delta} \\
\delta \\
0 \\
5 \\
\stackrel{0}{0}\end{array}$ & $\begin{array}{l}\text { ir } \\
0 \\
0 \\
0\end{array}$ & $\begin{array}{l}5 \\
8 \\
+ \\
8 \\
8\end{array}$ & $\begin{array}{l}\vec{\delta} \\
\vec{s} \\
\overrightarrow{8}\end{array}$ & $\begin{array}{l}g \\
0 \\
0 \\
0\end{array}$ & $\begin{array}{l}\overrightarrow{8} \\
8 \\
8 \\
8\end{array}$ & $\begin{array}{l}\text { gr } \\
0 \\
0\end{array}$ & $\begin{array}{l}5 \\
8 \\
0 \\
8\end{array}$ & $\begin{array}{l}\vec{g} \\
\vec{\delta} \\
\vec{\delta} \\
\overrightarrow{8}\end{array}$ & $\begin{array}{l}\stackrel{5}{5} \\
3 \\
\overrightarrow{8}\end{array}$ & 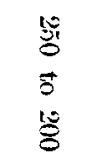 & 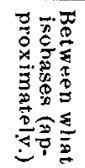 \\
\hline 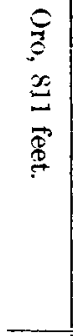 & 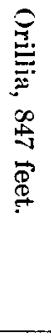 & 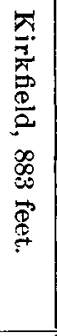 & 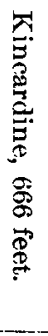 & 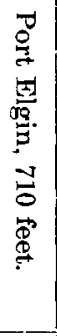 & 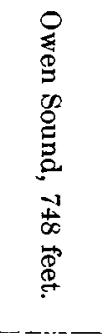 & 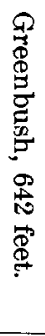 & 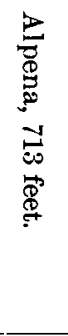 & 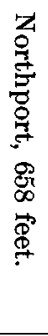 & 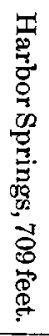 & 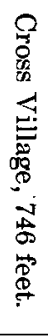 & 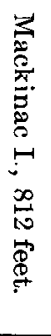 & 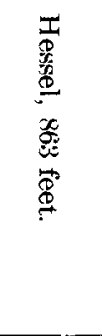 & 졍 \\
\hline 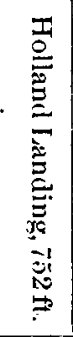 & $\begin{array}{l}0 \\
8 \\
0 \\
0 \\
\overrightarrow{0} \\
\overrightarrow{0} \\
?\end{array}$ & 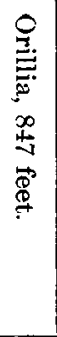 & 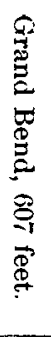 & 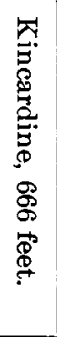 & 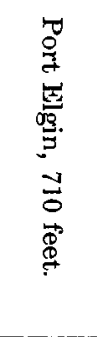 & 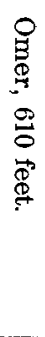 & 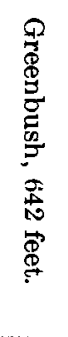 & 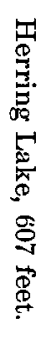 & 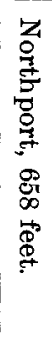 & 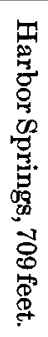 & 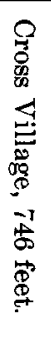 & 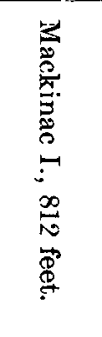 & \\
\hline $\begin{array}{l}2 \\
10 \\
0 \\
z\end{array}$ & 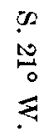 & $\begin{array}{l}n \\
N \\
\stackrel{N}{*} \\
\stackrel{Z}{*}\end{array}$ & 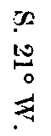 & $\begin{array}{l}02 \\
\Sigma \\
0 \\
0 \\
\Sigma\end{array}$ & \begin{tabular}{l}
5 \\
1 \\
0 \\
0 \\
\multirow{2}{*}{}
\end{tabular} & 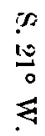 & 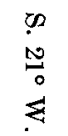 & $\begin{array}{l}0 \\
0 \\
0 \\
0 \\
\vdots \\
\end{array}$ & 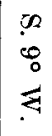 & $\begin{array}{l}0 \\
0 \\
0 \\
0 \\
\end{array}$ & 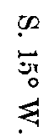 & 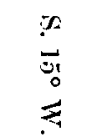 & 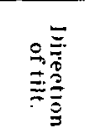 \\
\hline ثِ & $\ddot{\sigma}$ & 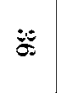 & تै' & 忠 & 诺 & 诧 & $\beth$ & $\Omega$ & $\underset{ت}{ت}$ & $\underbrace{+\infty}_{-1}$ & F & $\ddot{\Xi}$ & 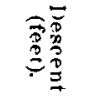 \\
\hline 㤐 & సo & 0 & $x$ & $\mathbf{N}$ & $\vec{\infty}$ & $\vec{E}$ & 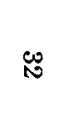 & $\vec{\Delta}$ & $\infty$ & $\Rightarrow$ & 今ั & $\overrightarrow{\mathrm{G}}$ & 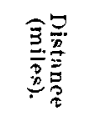 \\
\hline$\stackrel{10}{*}$ & $\ddot{\Xi}$ & $\bar{\Xi}$ & $\overrightarrow{\mathrm{s}}$ & $\stackrel{! *}{0}$ & $\stackrel{10}{=}$ & ì & 10 & ï & 亦 & \begin{tabular}{l}
10 \\
$\infty$ \\
\hdashline \\
\hdashline
\end{tabular} & 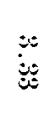 & $\begin{array}{l}\ddot{3} \\
\dot{5}\end{array}$ & 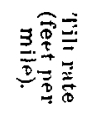 \\
\hline
\end{tabular}


table. Plate 5, although a small-scale map, does not exaggerate the uniformity.

\section{THE HORIZONTAL PORTION OF THE ALGONQUIN PLANE}

Around the southern half of Lake Michigan, and near the south ends of Saginaw Bay and Lake Huron, the Algonquin beach is almost, if not quite, horizontal. The identity of the beach is somewhat obscured by the presence of another strong shoreline, the Nipissing, which stands only about 12 feet below the Algonquin in both basins and which replaces it for long distances where cliff recession has been rapid and long continued. ${ }^{10}$ Moreover, cliff recession along the modern lake front has destroyed considerable stretches of both of these ancient strands. Nevertheless, the data collected seem complete enough to show that the Algonquin beach is virtually horizontal over this wide area.

'The following table gives the altitudes of the Algonquin beach or its supposed equivalent at 19 localities in or near the region of horizontality. All the measurements except the one at Port Sanilac were made with the wye-level :

Altitudes of the Algonquin Beach in the Region of Horizontality.

\begin{tabular}{|c|c|c|c|}
\hline Locality. & $\begin{array}{l}\text { Alti- } \\
\text { tude. }\end{array}$ & Authority. & Reference. \\
\hline Two Rivers, Wisconsin.. & $\begin{array}{l}\text { Feet. } \\
607\end{array}$ & Goldthwait. & $\begin{array}{l}\text { Bulletin Wisconsin Geological } \\
\text { and Natural History Survey, } \\
\text { No. 17, } 1906 \text {, page } 60 \text {, figure } \\
11 \text {, and plate } 12 \text {. }\end{array}$ \\
\hline Evanston, Illinois...... & 605 & Goldthwait. & $\begin{array}{l}\text { Bulletin Illinois Geological Sur- } \\
\text { vey, No. } 7,1908 \text {, pages } 64-65 \text {. }\end{array}$ \\
\hline $\begin{array}{l}\text { Rogers Park, Illinois .... } \\
\text { Holland, Michigan..... }\end{array}$ & $\begin{array}{l}604 \\
604\end{array}$ & $\begin{array}{l}\text { Goldthwait. } \\
\text { Taylor and } \\
\text { Goldhwait }\end{array}$ & $\begin{array}{l}\text { Idem, page } 66 . \\
\text { U. S. Geological Survey. }\end{array}$ \\
\hline Spring Lake, Michigan.. & 603 & Taylor and & T. S. Geological survey. \\
\hline IIuskegon, Michigan ... & 604 & $\begin{array}{l}\text { Taylor and } \\
\text { Goldthwait. }\end{array}$ & U. S. Geological Survey. \\
\hline Arcadia, Micligan...... & 603 & Taylor and & U. S. Geological Survey. \\
\hline Herring Lake, Michigan. & 607 & Taylor and & U. S. Geological Surver. \\
\hline Frankfort, Michigan..... & 605 & Taylor and & U. S. Genlogical Survey. \\
\hline Worth, Michigan........ & 607 & $\begin{array}{c}\text { Taylor and } \\
\text { Goldth wait. }\end{array}$ & U. S. Geological Survey. \\
\hline
\end{tabular}

10 See Abandoned shorelines of eastern Wisconsin. Bulletin of the Wisconsin Geological and Natural History Survey, no. 17, 1906, pp. 44-45; and Reconstruction of water-planes of the extlnct glacial lakes in the Lake Michigan basin. Journal of Geology, vol. 16, 1908, pp. 459-476. In the latter the altitude of the Algonquin beach was placed provisionally at 596 feet instead of 607 feet. The statement was made, ho ever, that this 596-foot beach might prove to be the Nipissing, and that the Algon:quin might be expected at 607 feet (see p. 472). 
Altitudes of the Algonquion Beach in the Region of Horizontality-('ontinued.

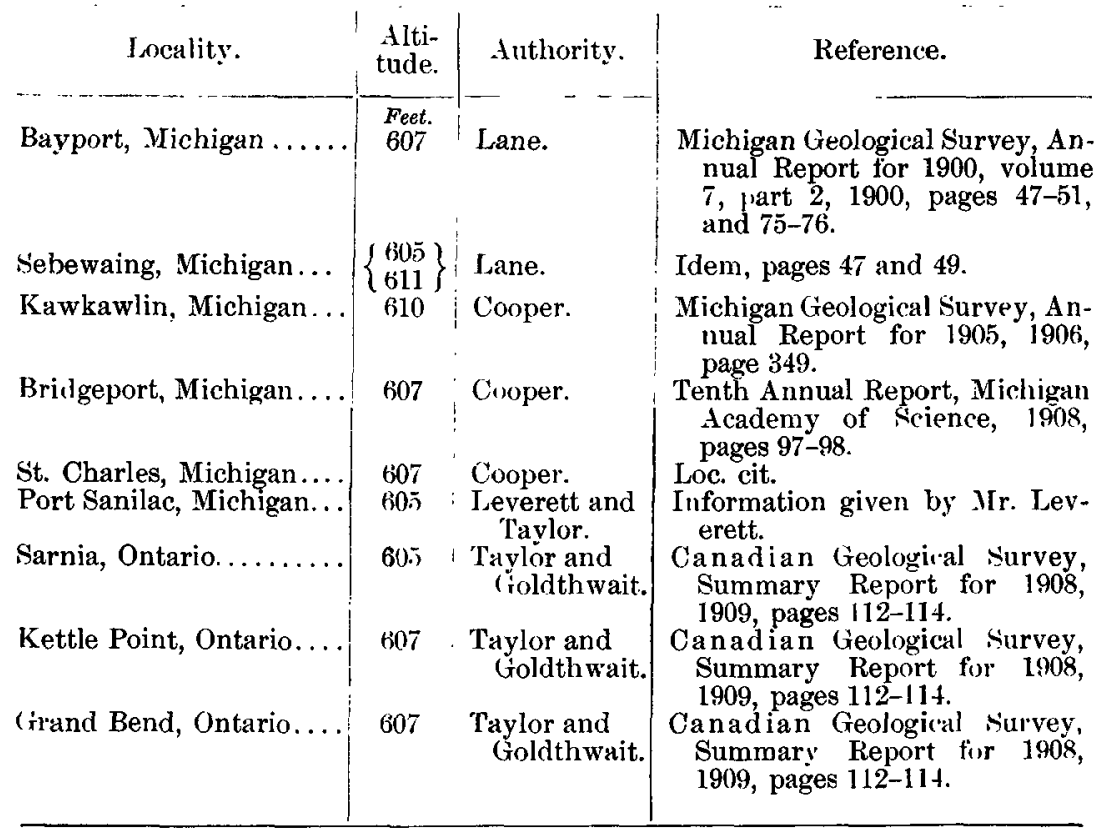

Between the first two localities in this table there is a stretch of $\mathbf{1 5 0}$ iniles in which no remnant of a beach at the 605-60\%-foot level has been discovered. The beach at 'Two Rivers is surely the Algonquin; the one at Evanston until recently was regarded as the shoreline of a local lake of the Michigan basin--Lake Chicago. The reasons for correlating it with the Algonquin are: $(a)$ its strength; $(b)$ its uniform altitude of 603-610 feet around the south end of Lake Michigan; $(c)$ the horizontal attitude of the Glenwood and Calumet beaches of Lake Chicago, which stand above it; $(d)$ the presence in it of molluscan shells, which are absent from the higher beaches; $(e)$ the occurrence of forest beds beneath the beach gravels, believed to record the stage of low water during the earlier part of the activity of Algonquin River, and $(f)$ evidences of erosion of cetrain valleys tributary to Lake Michigan to low levels, previous to the construction of this beach, as if to record the low-water stage just mentioned. ${ }^{11}$

\footnotetext{
14 On these points see Leverett: The Illinois glacial lobe. Monograph of the U. S. Geological Survey, vol. 38, 1899, pp. 445-453.

W. C. Alden: Chicago Follo, No. 81. Geological Atlas of the United States, U. S. Geological Survey, 1902, pp. 10-11.

Goldthwait: Bulletin of the Wisconsin Geological and Natural History Survey, no. 17, 1906, pp. 109-111, 118; and Bulletin of the Illinols Geological Survey, no. 7, 1908. pp. 65-66.
} 
For the Lake Michigan district these measurements give an average of 605 feet. Measurements with hand-level and aneroid barometer and contours of a large-scale map of the Sanitary District of Chicago agree in putting the height of the "Toleston," or "Algonquin," beach close to 600-605 feet around the south end of Lake Michigan. At the south ends of Saginaw Bay and Lake Huron the measurements average 607 feet. The altitudes at all 19 localities range from 603 to 610 feet. All of this variation of $\because$ feet can be accounted for by original differences in height of construction of the beach by the lake.

Even if we take the strong 596-foot (Nipissing) shoreline of the Lake Michigan basin as the equivalent of the 607 -foot beach of the Lake Huron basin (although in the latter basin also is a strong shoreline at 596 feet, which seems surely to be the equivalent of the Nipissing beach of the Michigan basin), the extreme variation in height is between 593 feet and 610 feet, and of 40 wye-level measurements already recorded only one is below 595 feet. Thus for 350 miles from east to west and for 200 miles from north to south there is a variation of scarcely 17 feet in altitude, at most, of the Algonquin beach, and, if the distinction between the Algonquin and the Nipissing shorelines has been correctly made, of not more than 7 feet.

'That the beaches around the head of Lake Michigan give little indication of differential uplift has long been recognized by those at work in the district, as reference to papers by Leverett, Alden, and others given above will show. The gathering of wye-level measurements has simply put the conclusion on a more satisfactory basis than heretofore, and has shown that the horizontal condition is more nearly absolute than might previously have been supposed.

The horizontality of the Algonquin plane is also wholly in harmony with the conclusions reached by Ieverett and Taylor several years ago in the case of the beaches of lakes Maumee, Whittlesey, and Warren, around the sonth and west sides of Iuake Erie. For Lake Maumee, Leverett states that

"west of the Ohio-Pennsylvania line the slight varlations displayed by each of its beaches are no greater than may be found along the present shore of Lake Erie; but near the Ohio-Pennsylvania line a differential uplift has caused the beaches to increase percepttbly in altitude in passing eastward." 13

In the same region, the beach of Lake Whittlesey for a stretch of 200 miles varies less than 15 feet in altitude.

12 Leverett: Glacial formations and drainage features of the Erle and Ohin basins. Monograph of the U. S. Geologlcal Survey, vol. 41. 1902, p. 739, 
"A part of this difference [of altitude] may be due to discrepancies between the railroad surveys and a part to the difference in height to which the beach was built above mean lake level. These elements of error and of variation being eliminated, it is doubtful if enough difference will remain to require any crust warping." 18

Similar statements are made by Leverett with regard to the beach of Lake Warren. ${ }^{14}$

The horizontality of the southern portion of a water-plane only 500 miles west of Lake Michigan was strongly suspected, indeed, as long ago as the ' 80 's, when J. E. Todd and Warren Upham secured measurements of altitude of the beaches of glacial lakes Agassiz and Dakota. In his monograph on Lake Agassiz, Upham says, with reference to Todd's data:

"It is evident . . . that the long area of Lake Dakota has experienced only slight differential changes of level, at least in the direction from south to north since the departure of the ice. The James River Valley is thus strongly contrasted with the northern uplifting that has affected the Red River Valley, as shown by the beaches of Lake Agassiz." is

De Geer remarked, in 1892:

"As Prof. J. E. Todd and Mr. Upham have stated, the deserted shores of Lake Dakota, situated close to the southwest of Lake Agassiz, show no or only a slight unequal deformation. As the longer axis of this lake trends in nearly the same direction as the greatest warping of Lake Agassiz, it seems probable that the limit for this warping and at the same time for the upheaved area lies just between Lake Agassiz and Lake Dakota, or through Lake Traverse."

THE "HINGE LINE" OR "ISOBASE OF ZERO"

The line which separates the region in which a beach has been upwarped from that in which it is still horizontal has been called by Leverett a "hinge line."17 Becanse of its definite implication of warping on one side and stability or uniformity on the other, this term seems preferable to "isobase for zero," which was used by De Geer. The latter term, unless qualified by a more definite phrase, allows the interpretation that on one side of the line there has been differential uplift and on the other

\footnotetext{
18 Idem, p. 756.

It Idem, p. 765 .

15 Upham: The glacial Lake Agassiz. Monograph of the U. S. Geological Survey, vol. 25, 1895, p. 267.

${ }^{16}$ De Geer: Proceedings of the Boston Society of Natural History, vol. 25, 1892, pp. 471-472.

17 This term was suggested to $\mathrm{Mr}$. Leverett by the facts in the Erle basin, but has not been used by him in print. It has been used by Coleman in a different sense, to mean a node line drawn from an extinct outlet through points where a beach splits vertically hecause of uplifts of that outlet. (See Coleman, Bulletin of the Geological Society of America, rol. 15, 1904, p. 363.)
} 
side differential depression. It is interesting to see, however, that De Geer, in employing "isobase for zero," seems to have thought of it as a hinge line. In his remarks on the deformation of the shorelines of lakes Agassiz and Dakota, already quoted, he makes "isobase for zero" equivalent to "the limit for the uplifted region," and although he dwells upon the uplift north of the lime, he says nothing to suggest depression south of it. "The conception of a "hinge line" is, therefore, no new one.

Upham, De Geer, and others long ago recognized that successive uplifts probably did not hinge on the same line. ${ }^{18}$ This appears to be true in a measure in the case of the upwarpings of water-planes of the Lake Michigan basin, for the northern limit of horizontality of the beaches of Lake Chicago is near the latitude of Milwaukee, Wisconsin, and Grand Haven, Mjchigan, while the corresponding Jimit for the Algonquin plane is about $\mathbf{1 0 0}$ miles farther north. Measurements of altitude of the plane of the later Nipissing shoreline, however, indicate that all post-Algonquin deformations hinged on a single line. ${ }^{10}$

\section{THE ALGONQUIN PLANE AS A DATUM PLANE}

It has been stated that south of the "hinge line" the Algonquin beach varies at most but 17 feet, and probably not more than 7 feet in altitude for 350 miles from east to west and 200 miles from north to south. Although this region may possibly have been raised or depressed from its original position so uniformly as not to warp the beach perceptibly, such a movement seems hardly probable. A variation of at least 20 or 30 feet might he looked for in such long distances. While recognizing the possibility of an even uplift or depression, therefore, we may reasonably favor the idea that in the region of horizontality the Algonquin beach stands today very nearly, if not precisely, where it stood when made.

Since the beach itself in this region has an average altitude of 605-607 feet above sealevel, the calm-water level of Lake Algonquin at this stage may be placed at 600 feet. This figure is open to certain corrections, however, for conditions peculiar to the latter part of the glacial period, chief among which is the lowered sealevel which resulted from the storing up of water in the ice-sheet. ${ }^{20}$ According to Upham, the sealevel during the stage of greatest glaciation may have been 100 or 150 feet below its normal position. ${ }^{21}$ By the time the ice-sheet had melted back

\footnotetext{
18 See passages just referred to, and especially Upham, op. clt., p. 481.

${ }^{14}$ Goldthwalt: Journal of Geology, vol. 16, 1908, pp. 473-474.

2n R. S. Woodward: On the form and position of the sealevel, Bulletin of the U. S. Feological Survey, no. 78,1888, p. 60 ,

at Tipham : op. cit., pp. 515-516,
} 
to the northern border of lake Algonquin, however, a considerable portion of this water must have been restored to the sea. Hence the correction to be added to the 600 -foot altitude of the Algonquin beach is probably much less than 100 feet.

This horizontal plane is a useful plane of reference from which to estimate the amount of post-Algonquin uplift of more northerly districts. ${ }^{22}$ 'The figures $50,100,150$, etcetera, on the isobases in plate 5 may, therefore, be conceived to indicate not simply the excess of uplift along those lines over uplift south of the "hinge line," but the total amount by which the altitudes of points on those lines have been increased since the time of the Algonquin beach. ${ }^{23}$

\section{The Iroquols Water-Plane}

\section{RELATIVE AGES OF THE IROQUOIS BEAOH AND THE ALGONQUIN BEACH.}

The outline of Lake Iroquois in figures 1 and 2 is based on several maps, but especially those of Gilbert, ${ }^{24}$ Fairchild, ${ }^{25}$ and Coleman. ${ }^{26}$ 'The location of the ice border, however, is wholly hypothetical, and shows only in a rough way the position of the Ontario ice-lobe as a barrier against the northwest side of the Adirondacks. The outlet into the Mohawk Valley at Rome, New York, is also shown.

It has long been thought that Lake Iroquois for at least a part of its existence was a contemporary of Lake Algonquin. The channel of the ancient Algonquin River, apparently connecting the two lakes, first suggested this relation. ${ }^{27}$ More particularly, evidence seemed to have been found in a great delta built by the Algonquin River near Peterboro, Ontario, at about the level of the Iroquois Beach. ${ }^{28}$ Gilbert, however, remarked that the correlation of this delta with the Iroquois beach was doubtful, and Coleman has more recently stated that the delta was built in a small tributary lake, which he names Iake Peterboro. ${ }^{29}$ We can not

\footnotetext{
22 The earliest printed statement of this idea is probably this sentence in fine print in Leverett's report on the surface geology of Alcona County, Michigan Geological Survey. Annual Report for 1901, p. 53: "The departure from horizontality here in Michigan may, therefore, be taken as a measure of the amount of uplift that has occurred."

23 Goldthwait: The attitude of the Algonquin beach and its significance. (Abstract.) Science, new ser., vol. 28, 1908, pp. 382-383.

24 G. K. Gllbert: The history of Niagara River. Sixth Annual Report of the Commissioners for the State Reservation at Niagara, 1890, pp. 61-84, map, pl. 5.

2s H. L. Fairchild: Twentleth Annual Report of the New York State Geologist, 1902, pl. 19 ; and Bulletin of the New York State Museum, no. 127, 1909, pl. 42.

${ }^{26}$ A. F. Coleman : Bulletin of the Geological Soclety of America, vol. 15, 1904, pl. 22.

27 Spencer: Proceedings of the American Association for the Advancement of Sclence. vol. 37,1888 , pp. 198-199.

${ }^{23}$ Gilbert: The Algonquin River. (Abstract.) American Geologlst, vol. 18, 1896, p. 231.

20 Coleman : op. cit., pp. 357-358.
} 
conclude, therefore, that the Peterboro delta and the Iroquois beach are synchronous, and consequently that the Iroquois beach, the Algonquin River, and the Algonquin beach are synchronous. Indeed, Gilbert's observation that the channel of Algonquin River continues down the Trent Valley below the plane of the Iroquois beach to Lake Ontario may be quoted as evidence that Lake Iroquois had already disappeared before the Algonquin River ceased to drain Lake Algonquin $;^{30}$ in other words, that the Iroquois beach is of earlier date than the Algonquin beach. On figure 2 the Iroquois shoreline is drawn as a dotted line, because of this evidence that the two lake stages are not strictly synchronons.

The question, therefore, arises: "How much older is the Iroquois beach than the Algonquin beach ?" Some light can be thrown on the question by examining and comparing the respective water-planes.

\section{ISOBASES OF THE IROQUOIS PLANE}

For plotting isobases of the Iroquois beach, measurements have been selected from those made by Gilbert, ${ }^{31}$ Spencer, ${ }^{32}$ Coleman, ${ }^{33}$ and Fairchild. ${ }^{34}$ Of these, Coleman's paper is of peculiar interest because his conclusions concerning the attitude of the Iroquois plane are matched very closely by those since reached for the Algonquin plane. The measurements are as follows:

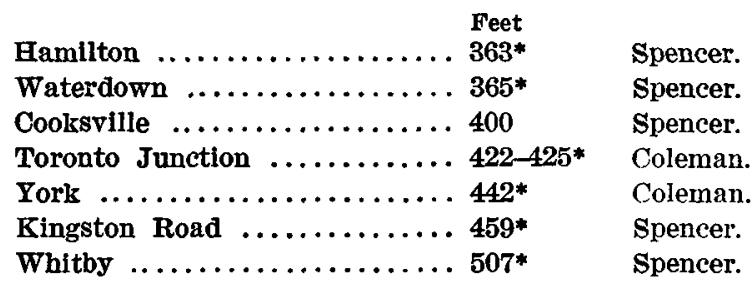

so Gilbert : loc. cit.

31 G. K. Gllbert: OId shoreline of Lake Ontario. (Abstract.) Science, vol. 6, 1885, p. 222 .

Old shorelines in the Ontario basin. Proceedings of the Canadian Institute, 3d ser., vol. 6,1888 , pp. 2-4.

39 J. W. Spencer: Deformation of the Iroquois beach and birth of Lake Ontario. American Journal of Science, 3d ser.. vol. 40, 1890, pp. 443-451.

On the focus of regional post-glacial uplift. Transactlons of the Royal society of Canada, sec. 4, vol. 7,1889 , p. 129.

Evolution of the falls of Niagara. Geological Survey of Canada, 1907, pp. 203-204. 208, 277-284.

A. F. Coleman : op. cit., especially pp. 358 and $359-362$.

\& H. L. Fairchild: Pleistocene geology of western New York; report of progress for 1900. Twentieth Annual Report of the New York State Geologist, 1902, pp. 103-139. Gllbert Gulf (marine waters in the Ontarlo basin). Bulletin of the Geological Society of America, vol. 17, 1906, pp. 712-718.

Glacial waters in central New York. Bulletin of the New York State Museum, no. 127, 1909 , pp. 54-55.

The measurements at Albion, Rochester, Auburn, Sodus, Rome, and Farrs were supplied by Professor Fairchlld from his unpublished data. 


\begin{tabular}{|c|c|}
\hline \multicolumn{2}{|l|}{ Feet } \\
\hline Quays Siding . . . . . . . . . 557 & Goleman. \\
\hline Colborne $\ldots \ldots \ldots \ldots \ldots \ldots \ldots$ 602* & Spencer. \\
\hline Trenton $\ldots \ldots \ldots \ldots \ldots \ldots \ldots$ 632* & Coleman. \\
\hline Queenstown & Spencer. \\
\hline Albion ... & Fairchild. \\
\hline Rochester . . . . . . . . . . . . 440 & Fairchild. \\
\hline Sodus $\ldots \ldots \ldots \ldots \ldots \ldots \ldots \ldots .456$ & Fairchild. \\
\hline Auburn $\ldots \ldots \ldots \ldots \ldots \ldots \ldots \ldots 411$ & F'airchild. \\
\hline Canastota $\ldots \ldots \ldots \ldots \ldots \ldots .441$ & Gilbert. \\
\hline Rome $\ldots \ldots \ldots \ldots \ldots \ldots \ldots \ldots \ldots 460$ & Fairchild. \\
\hline Cleveland $\ldots \ldots \ldots \ldots \ldots \ldots \ldots 484$ & Gilbert. \\
\hline Constantia $\ldots \ldots \ldots \ldots \ldots \ldots \ldots 489$ & Gilbert. \\
\hline Richland $\ldots \ldots \ldots \ldots \ldots \ldots \ldots 566$ & Fairchild. \\
\hline Adams $\ldots \ldots \ldots \ldots \ldots \ldots \ldots 640$ & Fairchild. \\
\hline Adams Center . . . . . . . . . . 657 & Gilber't. \\
\hline Brookside Cemetery ......... 700 & Fairchild. \\
\hline Farrs (east of Watertown)....733 & Fairchild. \\
\hline
\end{tabular}

* These are wye-level measurements.

These measurements have been plotted at the respective localities on plate 5, and isobases have been drawn across Lake Ontario with reference to them. It will be noticed that the altitude of the Iroquois beach at York (442 feet) is nearly equal to that at Rochester ( 440 feet) and that at Canastota (141 feet). The isobase drawn nearly through these localities, therefore, serves to fix the probable direction of tilt at that altitude. It indicates what Fairchild and other writers have remarked, that the direction of tilt is more nearly due southward over the east end of Lake Ontario than orer the west end. The same feature is met also in drawing isobases from Quays Siding ( 557 feet) to Richland (566 feet) and from 'I renton ( 632 feet) to Adams (640 feet).

Coleman found that the direction of inclination of the Iroquois plane over the western part of Lake Ontario is about south 20 degrees west. ${ }^{35}$ The isobases on plate 5 agree closely with his statement, running about 22 degrees sonth of east.

\section{Comparison of the Two Water-PLanes}

A comparison of the Iroquois isobases with the Algonquin isobases in southwestern Ontario brings out remarkable similarities of attitude in the two planes. The direction of tilt, as we have seen, is within one or two degrees of south 20 degrees west in both cases. This obviously means that the two beaches have been deformed by the same set of movements.

\footnotetext{
${ }^{85}$ Coleman : op. cit., p. 360.
} 
A still more remarkable resemblance between the Iroquois and Algonquin planes is found when the tilt rates of the two are compared. It is a matter of some convenience that the measurements available on the Iroquois beach are so distributed that they afford the construction of a set of isobases at 100-foot intervals, if we take for our zero the altitude of the beach at its southernmost point, Hamilton (363 feet). This has been done in figure 3. It is well recognized that the differential uplifts which warped the Iroquois plane extended southward as far at least as the head of that lake, at Hamilton, and an unknown distance beyond. Hence, although we take a line through Hamilton (in the direction 22 degrees south of east) as a zero line, we must not forget that zero is not a true measure of the amount of differential uplift at that place. It is quite probable that the post-Iroquois uplift at Hamilton amounts to 15 or 20 feet. We may therefore call the line a "zero plus" line, and the others "100 plus," "300 plus," etcetera. Having done this (see plate 5), we may examine the tilt rates between these isobases and compare them with the tilt rates between corresponding isobases of the Algonquin plane in the adjoining district.

Table for the Comparison of Tüt Rates of the Iroquois and Algonquin Planes

\begin{tabular}{|c|c|c|c|c|}
\hline \multirow{2}{*}{$\begin{array}{l}\text { Portion of } \\
\text { plane } \\
\text { reppesented } \\
\text { (isobases). }\end{array}$} & \multicolumn{2}{|l|}{ Iroquois plane. } & \multicolumn{2}{|l|}{ Algonquin plane. } \\
\hline & Dala. & $\begin{array}{c}\text { Tilt rate } \\
\text { (feet per } \\
\text { mile) }\end{array}$ & Data. & $\begin{array}{l}\text { Tilt riste } \\
\text { (feet per } \\
\text { mile). }\end{array}$ \\
\hline 0 to 100 & $\begin{array}{l}\text { Hamilton ( } 363 \text { feet) to } \\
\text { Kingston road }(459 \\
\text { feet), } 42 \text { miles. }\end{array}$ & 224 & $\begin{array}{l}\text { Grand Bend ( } 607 \text { feet }) \\
\text { to Port Elgin (710 } \\
\text { feet), } 79 \text { miles. }\end{array}$ & 1.30 \\
\hline 100 to 200 & $\begin{array}{l}\text { Kingston road ( } 459 \text { feet) } \\
\text { to Quays ( } 557 \text { feet), } \\
32 \text { miles. }\end{array}$ & 3.06 & $\begin{array}{l}\text { Port Elgin ( } 710 \text { feet) to } \\
\text { Owen Sound ( } 748 \text { feet); } \\
\text { and Holland Landing } \\
\text { ( } 752 \text { feet) to Oro ( } 811 \\
\text { feet), } 40 \text { miles. }\end{array}$ & 2.43 \\
\hline 200 to 275 & $\begin{array}{l}\text { Quays (557 feet) to } \\
\text { Trenton ( } 632 \text { feet), } \\
18 \text { miles. }\end{array}$ & 4.17 & $\begin{array}{l}\text { Oro }(811 \text { feet }) \text { to Kirk- } \\
\text { field }(883 \text { feet }), \quad 18 \\
\text { miles. }\end{array}$ & 4.00 \\
\hline
\end{tabular}

The comparison shows in each case a somewhat steeper tilt for the Iroquis plane than for the Algonquin. This must be due in a measure to the fact that the zero isobase for the Algonquin plane marks the real limit of uplift, while the "zero plus" line for the Iroquois plane is probably a number of miles north of the true "hinge line." If we only know how far south of Hamilton to move the "zero plus" line to put it in the 
right position for a "hinge line," we might move the "100 plus," "200 plus," and "300 plus" lines southward to correspond, and we could then estimate the tilt rates more correctly. All these rates would, of course, be smaller after this correction than they appear in the table, because of the southward flattening of the plane; but the rate nearest the zero line would be affected most. The result of decreasing the tilt rates of the Iroquois plane in the table and of decreasing especially the rate of $2.2 \mathrm{t}$ feet per mile for the stretch between the 0 and 100 isobases, would be to make these tilt rates agree even more closely than before with the rates for corresponding stretches of the Algonquin plane.

The bearing of this similarity of attitude of the Iroquois and Algonquin water-planes upon the question of their relative ages is obvious. If, as Gilbert's observations seem to require, the Iroquois beach is older than the Algonquin, it can not be much older, for it has been tilted only a little more than the Algonquin. Uplifts are known to have been going on for some time previous to the two outlet stages of Lake Algonquin, and to have continued for some time after it. Yet the Iroquois beach seems scarcely to have been affected by those uplifts which preceded the two-outlet stage. The two beaches appear, therefore, to be almost 'synchronous. In other words, it appears that the Ontario ice-lobe had only recently withdrawn from the northwest slope of the Adirondacks when the Algonquin River ceased running and the Algonquin beach began to rise above the 600 -foot plane.

\section{The Isobases and the PRe-Cambrian Bodndary}

In his paper on "Quaternary changes of level in Scandinavia," 38 in 1891, De Geer said:

"The isanabases of Sweden were found to conform with the limits of the Scandinavian Azoic territory, and, according to the very latest determinations, not only in a general way, but also in many details. . . . The coincidence between the area of upheaval and the Azoic territory may possibly be explained by assuming that this territory, which is an old tract of erosion, has also been one of continental upheaval, which subsided during the ice age, for the greater part perhaps in consequence of the considerable ice-load, again rising after the release from the latter, though not to its former altitude."

Again, in his paper of the following year, ${ }^{37}$ De Geer emphasized "the coincidence of the uplifted area with the Scandinavian Azoic region. or what Suess has called 'the Baltic shield' . . a well-defined tract where

38 De Geer: Bulletin of the Geological Society of America. vol, 3, 1802. pp. 65-66.

77 De Geer: On Pleistocene changes of level in eastern North America. Proceedings of the Boston Society of Natural History, vol. 25, 1892, pp. 454-477. 
the old rocks are laid bare by erosion and the surrounding lands thickly cowered with younger sediment. The limit of the Baltic shield, where it has been directly observed, and perlatps everywhere. is marked by great faults. Now the isobase for zero, or the boundary for the uplifted area, seems all the way a little outside of the above-named limit, and follows very conspicuously its conrexities and concavities. Ijikewise all the other isobases point to a close convection between the upheaval and the geological . . . structure of the land. ${ }^{\prime 38}$

In the same paper, after reviewing the evidence then available for North America, De Geer writes:

"The conformity between ice load and subsidence seems to bave been still greater here than in Scaudinavia; and in this respect it will be very interesting to see what will result from a continued investigation of the warped beaches in the lake basin with its marked ice-lobes. . . . The connection between the subsidence and the geological structure of the earth's crust is perhaps not quite so striking as in Scandinavia. Still it seems probable that the Canadian Azoic or Archean region has changed its level more than the surrounding tracts. . . . The general confornity between the ice covering and the old Azoic plateäu makes it difficult, in the present state of our knowledge, in many cases to discern between the influence of these two circumstances." "so

The question thus raised is too difficult to be answered satisfactorily even yet, because too little is known of the course of isobases outside of the Michigan-Huron-Ontario basins. An examination of the isobases for even this limited portion of the Great Lake region, however, is not without interest.

In the first place, the recent detailed studies of the Algonquin plane have indicated in every district that local irregularities, if present, are immeasurably small. The uplift around such depressions as Green Bay, Wisconsin; Grand Traverse Bay and Saginaw Bay, Michigan, and Georgian Bay, Ontario, show accordance-not discordance-with the broader, deeper lake basins adjoining them. The wye-level surveys have discovered no looping of the Algonquin isobases where they cross the lakes, such as one might expect from the greater thickness of the ice-lobes in those basins which are bordered by concentric moraines. If the melting away of the ice-sheet was the immediate cause of the uplifts of the region, the irregular load of these late, lobate stages must have been a very small factor in the equation, perhaps because the ice-sheet at that time possessed but a small fraction of its original thickness. The isobases run in a general way parallel to the boundary of maximum glaciation, but they

ss De Geer : op. cit., pp. 458-459.

so Idem, pp. $473-474$. 
do not appear to conform at all to the more strongly lobate boundaries of later stages.

Comparing the Algonquin and Iroquois isobases with the pre-Cambrian boundary of Ontario (marked on plate 5 by a line of small crosses), we find a general parallelism. The pre-Cambrian boundary, to be sure, is much more irregular than the isobases; but some of its sinuosities may be ignored, since they indicate the presence merely of thin outliers of the sediments or of protruding inliers of the crystallines. The direction of the border of the crystallines seems not to depart for any considerable distance or to any considerable degree from the direction of the isobases.

Whether the Adirondack oldland in the east and the pre-Cambrian area of northern Wisconsin in the west were also central areas of uplift or not, around which the isobases of the Iroquois and Algonquin planes if extended would turn, is a question which can not be answered from data now at hand. Such measurements as are arailable give no indication of it.

In agreement with De Geer's statement, therefore, it may be said that the parallelism of isobases to the border of the pre-Cambrian oldland in Ontario is as suggestive as the parallelisin of isobases to the border of the glaciated area; that a causal connection between the area of longcontinued erosion, the area of glaciation, and the area of post-glacial uplift may fairly be inferred from the most recently collected facts.

\section{SummarX}

Detailed surveys of the Algonquin beach around Lake Michigan, Lake Huron, and Georgian Bay have recently yielded a body of accurate data from which a set of isobases can be constructed on the upwarped plane of the Algonquin beach at intervals of 50 feet. Incidentally a datum plane appears to have been established, from which one can estimate the amount of uplift in more northerly parts of the Great Lakes region since Algonquin time.

Fewer measurements of altitude of the Iroquois beach around Lake Ontario furnish ground for the construction of a set of isobases at 100foot intervals on the Iroquois plane.

The similarity between the two sets of isobases is remarkable, both as regards the direction and the amount of tilt indicated for corresponding parts of the planes. Accepting Gilbert's conclusion from physiographic evidence that the Iroquois beach is of earlier date than the Algonquin, we are led by this comparison of the two tilted planes to conclude that the difference in age between them is probably very slight. 
'The rough parallelism of the isobases with the glacial boundary on the one hand, and with the border of the pre-Cambrian oldland of Canada on the other, in connection with the marked increase of tilt rate near the latter boundary, seems to strengthen the position taken by De Geer ${ }^{40}$ twenty years ago, that in North America, as in Scandinavia, the central areas of the recent upwarpings were not merely centers of glaciation, but centers of continental uplifts of much earlier dates.

* In his view regarding the central area of uplift in Canada, De Geer followed Spencer, who as early as 1889 attempted to locate the precise center of post-Algonquin upwarpings in a paper "On the focus of regional post-Glacial uplift" (Transactions of the Royal Soclety of Canada, section 4, vol. 7,1889 , p. 129). Spencer reached the conclusion that the center or focus was on the height of land southeast of James' Bay. De Geer's isobases are concentric with that point. In view of the subsequent discovery of the far westward trend of the isobases of Lake Algonquin and Lake Agassiz, it now appears that if the uplifts centered around any one point, that point was much farther north than Doctor Spencer supposed, or that the uplifts centered along an axis which trends westward from his "focus." 